\title{
Research about characteristics of designs from industrial designers and product designers
}

\author{
Adis J. Muminovic ${ }^{1,2}$, Isad Saric ${ }^{2}$, Elmedin Mesic ${ }^{1,2}$, Nedim Pervan ${ }^{1}$, Muamer Delic ${ }^{1,2}$ \\ ${ }^{1}$ Department of Mechanical Design, University of Sarajevo, Faculty of Mechanical Engineering, Sarajevo, Bosnia and Herzegovina \\ ${ }^{2}$ Department of Product Design, University of Sarajevo, Academy of fine Arts, Sarajevo, Bosnia and Herzegovina
}

\section{Article Info}

Received Apr 9, 2019
Keyword:
Industrial design
Product design
Chair design
Design evaluation

\begin{abstract}
Difference between industrial designer and product designer is not precisely defined. There is a lot of discussions and misunderstandings about these two professions. What is the job of industrial designer and what is the job of product designer? This question if often asked from people, which want to hire someone to design a new product for them. Through this research, same real-life design contest is given to group of students from Faculty of Mechanical Engineering, Department of Mechanical Design, at Industrial design course and to group of students from Academy of Fine Arts, Department of Product Design as product design project. Goal of the contest was to design an upholstered chair for indoor use with a modern and refined style. Goal of this research was to find some unique characteristic of designs from industrial designers and product designers. Resulted designs were evaluated analysing the fulfilment of the requirements criteria defined by contest and analysing additional criteria, which is important for new product design. Analysing the resulted designs some important conclusions are made. Most important conclusion is that industrial designer can be product designer but product designer cannot be industrial designer. For product design, engineering knowledge is not necessary, but for industrial design, it is most important.
\end{abstract}

\section{Corresponding Author:}

Adis J. Muminovic ${ }^{1,2}$,

Department of Mechanical Design,

University of Sarajevo, Faculty of Mechanical Engineering,

Sarajevo, Bosnia and Herzegovina

Email: adis.muminovic@mef.unsa.ba

\section{Introduction}

When someone wants to learn what is the difference between industrial design and product design, he can simply look to its definitions. However, in the case of industrial design and product design the definition and differentiation are debated, they are often confusing and sometimes vary given the context in which they're used. Some people will say that, for all intents and purposes product design and industrial design are the same, a product designer and industrial designer play vary similar roles professionally and share almost the same goals. It can be noticed that people do not know the difference, especially general public. To many people, industrial design sounds more engineering based. Alternatively, product design sounds more creative, straightforward and simple. The connotation of each is very subjective and depends entirely on the previous experiences of the person you are talking to.

According to reference [1], word "design" is both a noun and a verb. The noun often refers to both tangible and intangible artificial outputs created by specific design disciplines: industrial design, engineering design, 
product design, fashion design, graphic design, and service design, etc. [2], [3], [4]. The verb 'design' usually describes a cognitive activity that improves a situation [5], [6], [7]. It is also described by a C-K theory where $\mathrm{C}$ represents concepts and $\mathrm{K}$ describes knowledge, where design is a systematic expansion of concept that simultaneously uses and creates knowledge [8], [9]. Some researchers claim that industrial design is just a part of product design [10], others thinks differently, they say product design is just a part of industrial design and all product designers are industrial designers but not all industrial designers are product designers [11].

In science, there is no distinguee difference between product design and industrial design, same scientific journals publish papers from both fields, and they are usually referred as design journals. There are cases where same design journals publish papers about clothes design [12], product design [13], industrial design [14], or design in general [15]. Also, there are a lot of papers which deal with products which are more connected to industrial designers, products like cars or electronic equipment, but through whole paper authors use product design terms, papers like reference [13]. Same example can be seen from reference [16], which deals with mobile phone design.

There is not exact time in modern history that can be noticed as time when product design started. It can be said that product design started with first product which is made by humans in prehistoric times. Those first products were shaped moistly regarding efficiently (products like weapons) and safety (product like wooden houses). Separating product design from industrial design is impossible. Over the years, designers or companies have chosen to use the term "product design" rather than industrial design as it is slightly more specific than the vast field of industrial design [11].

Product design is a procces that have a goal to design a product which is meant to be sold to consumers, whatever that product might be. It is how new things is designed, or new versions of things redesigned. Industrial design is the exact same thing, but it more pertains to things that have a functional value, especially things that require industrialization to produce. Items developed through industrial design are not necessarily designed for the sole benefit of the user, their design goals may make things easier for the manufacturing, assembly, recycling, amoung others.

Today, product design term is used more often than industrial design. Product design includes wide range of disciplines. Usually, product design includes everything connected to design: automobile design, furniture design, design of electrical products, software design, graphic design, web design, clothes design, etc. Only some researchers and stakeholders make the difference for some disciplines connected more to technical sciences and call them industrial design, disciplines like automobile design, furniture, electrical product design, etc. Different understanding and usage of these two terms is obvious.

At the 29th General Assembly in Gwangju (South Korea), the Professional Practice Committee unveiled a renewed definition of industrial design as a strategic problem-solving process that drives innovation, builds business success, and leads to a better quality of life through innovative products, systems, services, and experiences.

History of industrial design is more connected to industrial revolution. Before industrial revolution product was made by hand and cost much more to produce. After industrial revolution mass production become possible, price of the product become lower and more people were able to buy them. This way production cost become less important factor for selling the product, so other solution, how to sell new product, was needed. This moment can be marked as a moment when industrial design is introduced. People realised that product with better design have better sales. Mass production bring another problem, if someone produce a lot of same products, how to convince people to buy new product with same functionality if they already have one which can do the same. Industrial designers filled the role of creating incentives for consumers to buy the new massproduced products by adding features such as improving functionality, aesthetics and ergonomics. They did this through their knowledge of design. In order to increase sales, companies began hiring industrial designers to continually design new versions of the same products and sell them to customers year after year [11].

In reference [10] it is stated: "Industrial designers take a useful product that serves a need, and makes it even more useful or more beautiful. They are the ones who make new models of a car or improve the ergonomics 
of a chair or computer keyboard. They keep all our modern conveniences fresh and new, making them even more convenient as time goes on". In addition, in the same reference it is stated: "Product design encompasses everything that is a product, including those things covered by industrial design. While it helps for an industrial designer to be an engineer in his field, there's no such requirement for, say, a clothing designer or someone who develops food products or flatware. Today, product designers are also involved in the creation of products that have no tangible output, namely digital products like software." If both above mentioned facts are taken as true than following questions can be asked:

- Why product designers during study, at some faculties and design academies, have classes and courses which are engineering based, courses like technical documentation, CAD and simulation (stress, dynamic etc.) [17]? Why they need those courses if they want to do graphic design later at the job? Is it necessary to split product design study on product design for real physical objects and product design of digital products?

- Is there any unique characteristic of resulted designs from industrial designers in comparison to product designers and one versa?

- If someone wants a new product of something, for example a chair, who need to be hired, product designer or industrial designer?

- If someone wants to become a good designer, what he needs to study, industrial design or product design?

- $\quad$ Is it better to include some engineering courses to product design study program or to include some innovation and creativity courses to industrial design study programs?

- Is it easier to teach creative mind (product designer) some engineering skills, or is it easier to teach engineer (industrial designer) how to be creative?

Objective of this research, which is carried out in this paper is to try to answer as much, above-mentioned questions, as possible. Same real life design task is given to industrial designers and to product designers to try to answer to these questions. Similar research cannot be find from other authors, that is one of the reasons why general public is confused with these two concepts (industrial design and product design). Qestions that are not aswered in this reasearh will be addressed in future research and they are open to other authors to address it. One of the goal of this research is to start the discussion about this topic.

\section{Research Methodology}

Through this research same real-life design contest is given to group of students from Faculty of Mechanical Engineering, Department of Mechanical Design, at Industrial design course ('industrial designers' in the rest of the paper) and to group of students from Academy of Fine Arts, Department of Product Design as product design project ('product designers' in the rest of the paper). Goal of the contest was to design an upholstered chair for indoor use, with a modern and refined style. Resulted designs were evaluated with a goal to find some unique characteristic of resulted designs from industrial designers in comparison to product designers and one versa.

Evaluation of product designs can be done using a lot of different approaches and it plays a critical role in the early phases of product development. Also, it has significant impact on the downstream development processes as well as on the success for the product which is developed. It can be said that some evaluation methods are mathematically (technical/engineering requirements) based and others are based on emotions (aesthetics, emotional impact) or customer experience with the product [18]. What is more important for product succeed, product appearance or product performance is well discussed in reference [19] and [20]. As it is stated in reference [21] design concept evaluation is a complex multi-criteria decision-making process which involves large amount of data and expert knowledge which is usually imprecise and subjective.

Aiming to improve the effectiveness and objectivity of the design concept evaluation process, novel method based on grey relation analysis and rough set theory is proposed in reference [22]. Example of evaluation based on emotion is shown in reference [23]. These authors discussed an industrial designer's approach to eliciting user perceptions and emotional responses to products through visual evaluation and stimulation. While authors accept that product functionality is crucial for product success, the appearance, use of materials, shape and form provide the most immediate product data for the user. Less tangible issues such as emotional 
bonding of users with products, cultural perceptions and social value systems, provide valuable insights for the product developer to help expand knowledge and understanding of the users need beyond the functionality. One of the ways to evaluate product is through market analysis. Increasingly, the design of successful new industrial products is related to careful market assessment [23]. As it can be seen from above mentioned papers, a lot of different evaluation approaches are existing today. Analysing the fulfilment of the requirements criteria defined by contest and analysing additional criteria which is important for new product design, criteria like production complexity, versatility of use, degree of customisation, positive emotional impact, aesthetics of materials and degree of compliance with the context of use, are chosen as evaluation method for this research. More about this evaluation method can be find in references [24] and [25].

Except these evaluation criteria, resulted designs are analysed visually. Goal of visual evaluation is to find some unique characteristic of resulted designs from industrial designers in comparison to product designers and one versa.

\section{Luxy Chair Design Award contest}

Luxy Chair Design Award contest was offer at page [26]. Desall offers to companies and private clients a web platform dedicated to the conception and participatory development of new products in the industrial, craft and interior design fields. Clients who are looking for inspiration, creativity and product innovation can launch creative contests open to a worldwide community of designers, obtaining, at the same time, design solutions and international visibility.

\subsection{Design Requirements}

For chair design contest following requirements are given by the design contest and they should be fulfilled:

- $\quad$ Type of chair: Upholstered chair for indoor use, with a modern and refined style;

- $\quad$ Place of use: Both business and residential sector, including hotels, waiting rooms, offices, common areas.

- $\quad$ Product topology: Upholstered chair for indoor use, comfortable, with a modern style and appropriate for various contexts of use.

- $\quad$ Shape and functions: Refined and modern design.

- Materials: The chair can have internal structures made of metal and/or wood. The lining might be realised in fabric and/or leather.

- $\quad$ Size and weight: The size of the chair shall comply with the standard adopted for this product typology. There are no constraints regarding the weight of the chair, but designer needs to consider that it shall be handy enough for transportability and stacking.

- $\quad$ Style and colours: Chair shall have a modern and very refined design, paying particular attention to the brand style and compliance; and

Target: Chair will mainly address consumers with a medium-high/high purchasing power, presenting itself as a product with a great aesthetic value. The approximate production cost for the chair will be between $€ 80$ and $€ 130$.

Additionally, more evaluation criteria were noted as important in contest: production complexity, versatility of use, degree of customisation, positive emotional impact, aesthetics of materials and degree of compliance with the context of use. According to [24] all these requirements can be summarised into two categories:

- Technical: production complexity, materials, size and weight, degree of customisation, versatility of use; and

- Aesthetics: product topology, style and colours, positive emotional impact, shape and functions, aesthetics of materials.

\section{Evaluation of resulted designs}

Fig. 1 shows resulted designs from industrial designers and Fig. 2 shows resulted designs from product designers. It is important to notice that designs are completely done by the students, not by the authors of this research, authors was responsible to analyse resulted designs. To design the chair, students use methods and knowledge which they learn and gain during they industrial design and product design study program. 

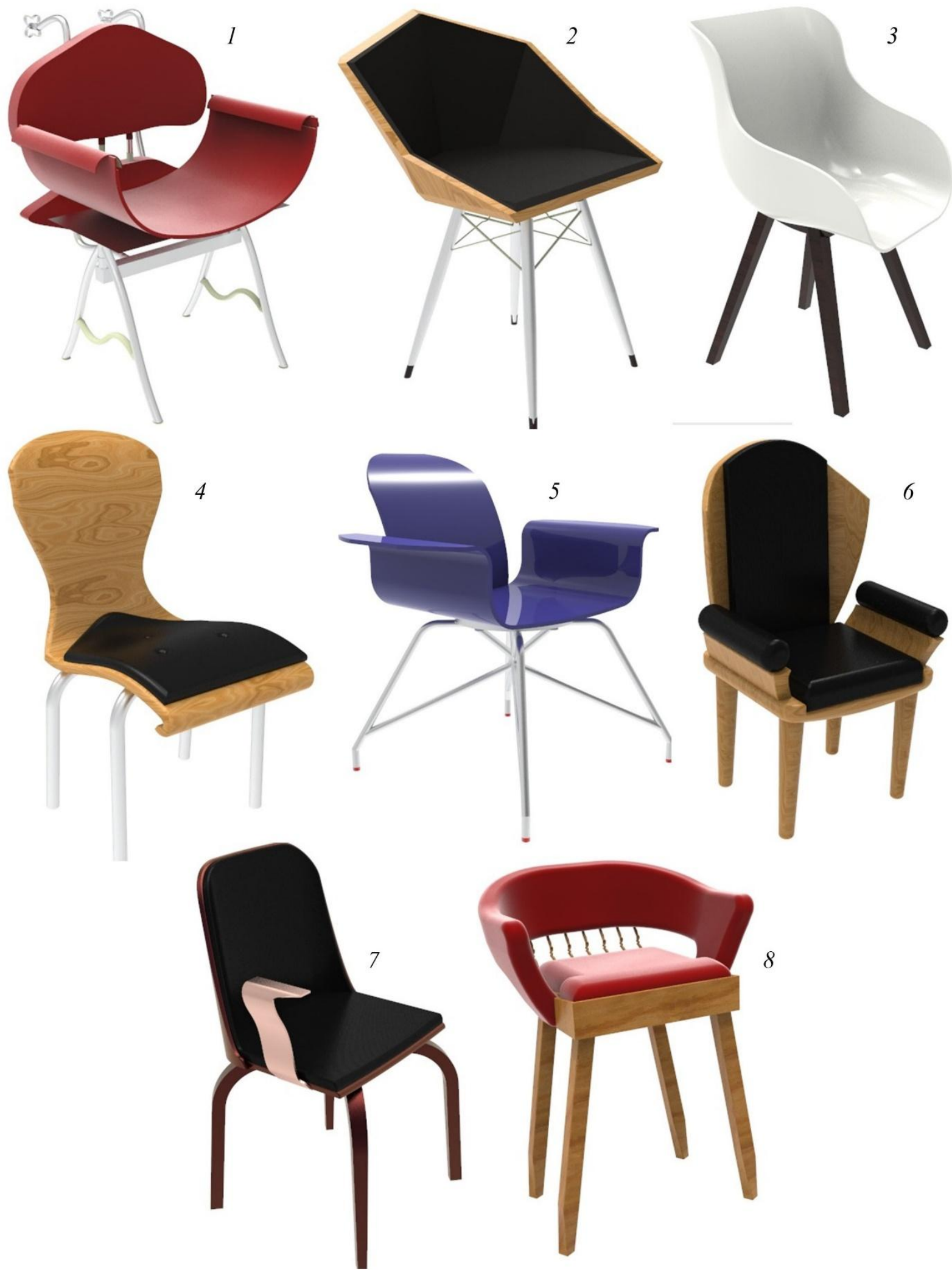

Figure 1. Resulted designs from industrial designers 

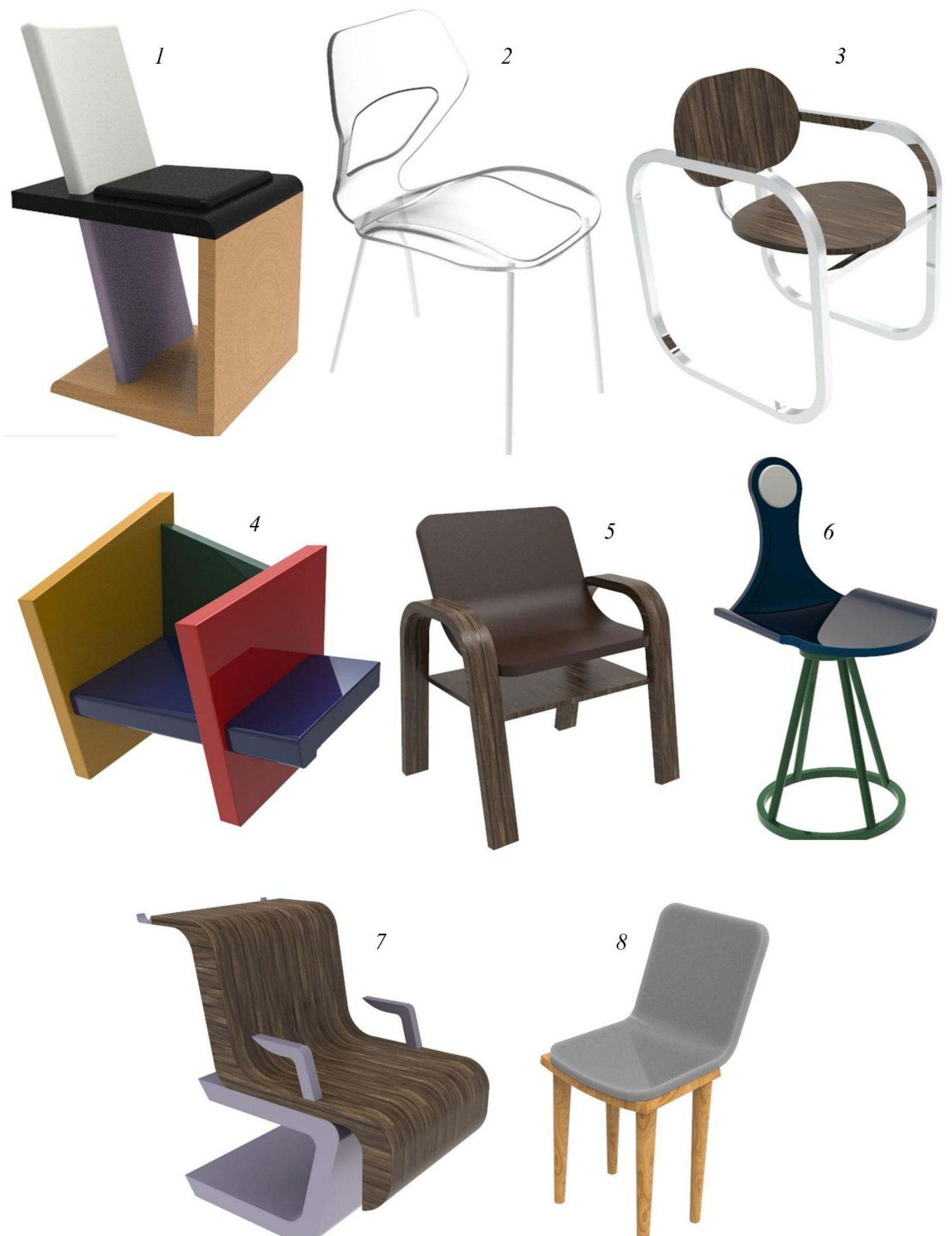

Figure 2. Resulted designs from product designers

The First step in evaluation process is to create evaluation table where every design will get a grade, from one (lowest) to ten (highest), for every individual criterion. 
Table 1. Evaluation of designs from Fig. 1. Resulted designs from industrial designers

\begin{tabular}{|c|c|c|c|c|c|c|c|c|c|}
\hline \multirow{2}{*}{\multicolumn{2}{|c|}{ Evaluation criteria }} & \multicolumn{8}{|c|}{ Design number } \\
\hline & & $\begin{array}{c}\text { No. } \\
1\end{array}$ & $\begin{array}{c}\text { No. } \\
2\end{array}$ & $\begin{array}{c}\text { No. } \\
3\end{array}$ & $\begin{array}{c}\text { No. } \\
4\end{array}$ & $\begin{array}{c}\text { No. } \\
5\end{array}$ & $\begin{array}{c}\text { No. } \\
6\end{array}$ & $\begin{array}{c}\text { No. } \\
7\end{array}$ & $\begin{array}{c}\text { No } \\
8\end{array}$ \\
\hline \multirow{5}{*}{ 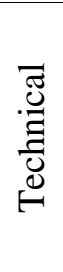 } & Production complexity & 3 & 4 & 5 & 6 & 4 & 6 & 5 & 5 \\
\hline & Materials & 3 & 9 & 7 & 9 & 7 & 3 & 8 & 3 \\
\hline & Size and weight & 9 & 10 & 10 & 10 & 10 & 9 & 10 & 9 \\
\hline & $\begin{array}{l}\text { Degree of } \\
\text { customisation }\end{array}$ & 5 & 7 & 7 & 6 & 9 & 3 & 4 & 3 \\
\hline & Versatility of use & 3 & 10 & 8 & 5 & 8 & 1 & 3 & 1 \\
\hline & Sum: & 23 & 40 & 37 & 36 & 38 & 22 & 30 & 21 \\
\hline \multicolumn{10}{|c|}{ Total sum of all designs for technical requirements: 247} \\
\hline \multirow{5}{*}{$\frac{\frac{0}{0}}{\frac{0}{0}}$} & Product topology & 5 & 10 & 9 & 8 & 9 & 3 & 7 & 3 \\
\hline & Style and colours & 5 & 10 & 9 & 9 & 8 & 5 & 7 & 5 \\
\hline & $\begin{array}{c}\text { Positive emotional } \\
\text { impact }\end{array}$ & 5 & 10 & 9 & 8 & 9 & 5 & 5 & 5 \\
\hline & Shape and functions & 6 & 10 & 10 & 9 & 10 & 5 & 8 & 5 \\
\hline & Aesthetics of materials & 5 & 10 & 9 & 7 & 9 & 5 & 7 & 5 \\
\hline & Sum: & 26 & 50 & 46 & 41 & 45 & 23 & 34 & 23 \\
\hline \multicolumn{10}{|c|}{ Total sum of all designs for aesthetics requirements: 288} \\
\hline \multicolumn{2}{|c|}{ Sum of technical + aesthetics: } & 49 & 90 & 83 & 77 & 83 & 45 & 64 & 44 \\
\hline
\end{tabular}

Table 2. Evaluation of designs from Fig. 2. Resulted designs from product designers

\begin{tabular}{|c|c|c|c|c|c|c|c|c|c|}
\hline \multirow{2}{*}{\multicolumn{2}{|c|}{ Evaluation criteria }} & \multicolumn{8}{|c|}{ Design number } \\
\hline & & $\begin{array}{c}\text { No. } \\
1\end{array}$ & $\begin{array}{c}\text { No. } \\
2\end{array}$ & $\begin{array}{c}\text { No. } \\
3\end{array}$ & $\begin{array}{c}\text { No. } \\
4\end{array}$ & $\begin{array}{c}\text { No. } \\
5\end{array}$ & $\begin{array}{c}\text { No. } \\
6\end{array}$ & $\begin{array}{c}\text { No. } \\
7\end{array}$ & $\begin{array}{c}\mathrm{No} \\
8\end{array}$ \\
\hline \multirow{5}{*}{ 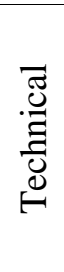 } & Production complexity & 6 & 5 & 6 & 6 & 6 & 4 & 5 & 6 \\
\hline & Materials & 9 & 6 & 7 & 8 & 7 & 7 & 8 & 3 \\
\hline & Size and weight & 9 & 10 & 10 & 7 & 9 & 9 & 7 & 9 \\
\hline & $\begin{array}{c}\text { Degree of } \\
\text { customisation }\end{array}$ & 5 & 3 & 6 & 5 & 5 & 9 & 4 & 2 \\
\hline & Versatility of use & 8 & 8 & 10 & 8 & 7 & 7 & 3 & 1 \\
\hline & Sum: & 37 & 32 & 39 & 34 & 34 & 36 & 27 & 21 \\
\hline & Total sum c & all de & ns fo & chnic & requ & nents & & & \\
\hline \multirow{5}{*}{ 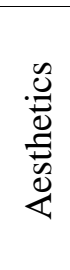 } & Product topology & 8 & 8 & 9 & 8 & 8 & 8 & 7 & 3 \\
\hline & Style and colours & 8 & 9 & 7 & 9 & 7 & 8 & 7 & 5 \\
\hline & $\begin{array}{c}\text { Positive emotional } \\
\text { impact }\end{array}$ & 8 & 9 & 9 & 10 & 6 & 6 & 5 & 5 \\
\hline & Shape and functions & 7 & 8 & 9 & 9 & 9 & 7 & 8 & 5 \\
\hline & Aesthetics of materials & 5 & 10 & 9 & 9 & 7 & 5 & 8 & 5 \\
\hline & Sum: & 36 & 44 & 43 & 45 & 37 & 34 & 35 & 23 \\
\hline \multicolumn{10}{|c|}{ Total sum of all designs for aesthetics requirements: 297} \\
\hline \multicolumn{2}{|c|}{ Sum of technical + aesthetics: } & 73 & 76 & 82 & 79 & 71 & 70 & 62 & 44 \\
\hline
\end{tabular}

Based on evaluation results from Table 1 and Table 2 following conclusion can be made.

Total grades are almost the same, difference is neglected. As total sum of all designs, for all requirements, product designers have better grades, but three individual designs from industrial designers have biggest grades. At first, everyone will expect that designs from industrial designers will be more technical correct and easier to production but les modern and with les refined style. Also, a lot of people will think that product 
designers will give more complex designs with better style and better aesthetics. In another words a lot of people will think that designs from industrial designers will have better grades for technical requirements and designs from product designers will have better grades for aesthetics requirements. None of these assumptions are correct in this case.

Designs from industrial designers vary a lot, in comparison to product designers which designs have almost the same grades, except for design number 8 . This can be result of the fact that industrial designers make a research of the market before starting design process and product designers try to make original design without taking in consideration already existing designs on the market. During study, industrial designers are taught to make analysis of the similar task before starting its own in all aspect of education. In another case, product designers are taught to try think differently from others, and always try to make something original and creative.

Industrial designers have better knowledge of 3D modelling, so they used more complex shapes for its designs, in comparison to product designers who used basic shapes like rectangles, circles and cubes, this is especially visible on designs number 1, 3, 4 and 7 from product designers. This can be taken as a proof that engineering skills like 3D modelling influencing significantly on resulted designs.

Design number 2 from industrial designer (Fig. 1) gets the best grade. It fulfilled all requirements given by the contest. Design number 2 is chair for indoor use, it can be used in both business and residential sector, it has a modern and refined style, it is comfortable, and materials are well used. Size and weight are great, colours are well chosen, and it enables a lot of variant for different colours. It has positive emotional impact because it has modern and comfortable style. There are only two low grades for this design, it has low degree of customisation and it is more complicated for production compared to the other designs. Designs number 3 and 5 from industrial designers and designs number 3 and 4 from product designers have similar grades as design number 2 from industrial designers. Only important difference is that materials are not well used. Lining, in the form of fabric or leather, as a cover for wood or metal is not used.

Other worth mentioned designs are design number 4 and 7 from industrial designers and designs number 1, 2, 5 , and 6 from product designers. The biggest problems for these designs are versatility of use and production complexity. They don't fit for use in both business and residential sector. This is especially the case with designs number 4 and 7 from industrial designers and design number 5 and 6 from product designers.

\section{Conclusion}

This research showed that industrial designers and product designers have a lot of in common. Difference between them is very small. Resulted designs depends more on designer experience, innovation and creativity, rather than education background as industrial designer or product designer. It can be noticed that resulted designs from industrial designers used more complicated shapes and they are more in line with others designs available on the market. In addition, it can be noticed that industrial designers think about production during design process. It is easy to choose production technology for all designs from industrial designers. For some designs from product designers additional research needs to be done to choose how to produce the chairs, especially designs number 1, 4 and 7. Designs from product designers show more creativity and originality.

Taking in consideration results from this research conclusion can be formulated in a way that if someone wants for a new product to be something totally new and original, without connection to other designs available on the market, he should hire product designer from Academy of Fine Arts. If someone wants new product which is more in line with other designs and more in line with production technology, he should hire industrial designer from Engineering Faculty. Future research needs to be done to better divide this two profession, and to better organize and prepare study programs for them.

Industrial designer can be product designer but product designer cannot be industrial designer. For product design engineering knowledge isn't necessary, for industrial design it is most important. 
It is necessary to say that industrial design can be learned, in comparison with product design which quality depends also on the talent of designer.

\section{References}

[1] J. Na, Y. Choi, and D. Harrison, "The Design Innovation Spectrum: An Overview of Design Influences on Innovation for Manufacturing Companies", International Journal of Design, Vol. 11, no. 2, pp. 13-24, 2017.

[2] K. Best, Design management: Managing design strategy, process and implementation, Lausanne, Switzerland: AVA Publishing SA., 2006.

[3] M. Bruce, and J. Bessant, What is design? In Bruce, M. and Bessant, J. (Eds.), Design in business: Strategic innovation through design (pp. 18-33). Harlow, UK: Pearson Education Limited, 2002.

[4] R. Cooper, and M. Press, The design agenda: A guide to successful design management. Chichester, UK: John Wiley \& Sons Ltd. 1995.

[5] H. A. Simon, The sciences of the artificial (3rd ed.). Cambridge, MA: MIT Press. 1996.

[6] R. Verganti, Design-driven innovation: Changing the rules of competition by radically innovating what things mean. Boston, MA: Harvard Business Press, 2009.

[7] W. Visser, "Design: One, but in different forms," Design Studies, Vol. 30, no. 3, pp. 187-223, 2009.

[8] A. Hatchuel, and B. Weil, "A new approach of innovative design: An introduction to C-K theory," Proc. 14th International Conference of Engineering Design (no. DS31_1794FPC), 2003, pp. 109-110.

[9] P. Le Masson, W. Benoit, and A. Hatchuel, Strategic management of innovation and design. Cambridge, UK: Cambridge University Press, 2010.

[10] E. Hunter, "What is the Difference between Product Design \& Industrial Design," http://michaelaldridge.com/thedifference-product-design-industrial-design/, July 22, 2018.

[11] W. Gibbons, “Industrial Design vs Product Design,” https://medium.com/@WillGibbonsDesign/industrial-designvs-product-design-810c34f612b0, March 24, 2015.

[12] O. Tomico, L. Hallnäs, R.-H. Liang, and S. A. G. Wensveen, "Towards a Next Wave of Wearable and Fashionable Interactions", International Journal of Design, Vol. 11, no. 3, pp. 1-6, 2017.

[13] O. Pedgley, B. Sener, D. Lilley, and B. Bridgens, "Embracing Material Surface Imperfections in Product Design", International Journal of Design, Vol. 12, no. 3, pp. 21-33, 2018.

[14] S. Park-Lee, and O. Person, "Briefing Beyond Documentation: An Interview Study on Industrial Design Consulting Practices in Finland", International Journal of Design, Vol. 12, no. 3, pp. 73-91, 2018.

[15] L. Sanchez-Moreno, and C. Dilnot, "John Heskett's Industrial Design: An Interview at Middlesex Polytechnic, 1981: Part One: Problems in Writing Histories of Design”, Design Issues, Vol. 35, no. 1, pp. 36-51. Winter 2019.

[16] C. Ho, Y. Lu, and C. Chen, "Influence of Curvature and Expertise on Aesthetic Preferences for Mobile Device Designs", International Journal of Design, Vol. 10, no. 3, pp. 17-25, 2016.

[17] A. Gomes, B. Rangel, V. Carneiro, and J. Lino, Learning by Doing Integrated Project Design in a Master Program on Product and Industrial Design. In M. M. Nascimento, R. A. Gustavo, and A. M. Eva Virgínia (Eds.), Contributions to Higher Engineering Education, Singapore: Springer, 2018.

[18] M. Y. El Ghoumari, A. Daif, R. Moulouki, H. Jihal, and M. Azzouazi, "Architectural Design of Trust Based Recommendation System in Customer Relationship Management", Periodicals of Engineering and Natural Sciences, Vol. 6, no. 2, pp. 380-388, 2018.

[19] M. Yamamoto, and D.R. Lambert, "The Impact of Product Aesthetics on the Evaluation of Industrial Products", The Journal of Product Inovation Management, Vol. 11, no. 4, pp. 309-324, 1994.

[20] M. N. Folkmann, "Evaluating Aesthetics in Design: A Phenomenological Approach", Design Issues, Vol. 26, no. 1, pp. 40-53, Winter 2010.

[21] L.-Y. Zhai, L.-P. Khoo, and Z.W. Zhong, "Design Concept Evaluation in Product Development Using Rough Sets and Grey Relation Analysis", Expert Systems with Applications, Vol. 36, no. 3-2, pp. 7072-7079, 2009.

[22] D. McDonagh, A. Bruseberg, and C. Haslam, "Visual Product Evaluation: Exploring Users' Emotional Relationships with Products", Applied Ergonomics, Vol. 33, no. 3, pp. 231-240, 2002.

[23] R. L. Keeney, and G. L. Lilien, "New Industrial Product Design and Evaluation Using Multiattribute Value Analysis", The Journal of Product Inovation Management, Vol. 4, no. 3, pp. 185-198, 1987. 
[24] G. Pahl, W. Beitz, J. Feldhusen, and K.-H. Grote, Engineering Design A Systematic Approach, London, SpringerVerlag London, 2007.

[25] I. Saric, and A.J. Muminovic, Product Development and Design. Sarajevo, BiH: Faculty of Mechanical Engineering. 2018.

[26] https://desall.com/Contest/Luxy-Chair-Design-Award/Brief, Accessed 18.03.2019. 